\title{
KEDUDUKAN ISTIMEWA MEREK TERKENAL (ASING) DALAM HUKUM MEREK INDONESIA ${ }^{1}$
}

\author{
Lionita Putri Lobo, Indirani Wauran* \\ Fakultas Hukum, Universitas Kristen Satya Wacana \\ J1. Diponegoro No. 52-60 Sidorejo, Salatiga, Jawa Tengah, 50711 \\ indirani.wauran@uksw.edu
}

\begin{abstract}
The first to file registration system is considered not to provide protection and legal certainty for well-known trademark owners. A brand known for its famous status has a special position. The purpose of writing this article is to argue that even though a well-known brand has not been registered in Indonesia, it is still privileged because of its famous phrase. The method used in this research is the normative. Indonesia should protect well-known marks even though they are not registered in the general list of marks, as regulated in the TRIPs Agreement and the Paris Convention. The TRIPs Agreement and the Paris Convention must be used as a source of law by Indonesia as a consequence of participating in the WTO to provide protection and legal certainty for well-known trademark owners.
\end{abstract}

Keywords: Trademark Protection; Well-Known Mark; First to File.

\begin{abstract}
Abstrak
Sistem pendaftran first to file dinilai belum memberikan perlindungan dan kepastian hukum bagi pemilik merek terkenal. Merek terkenal karena status terkenalnya mempunyai kedudukan yang istimewa. Adapun tujuan penulisan artikel ini untuk memberikan argumentasi bahwa merek terkenal sekalipun belum terdaftar di Indonesia tetap mendapat keistimewaan karena frasa terkenalnya. Metode yang digunakan dalam penelitian ini, yaitu penelitian hukum normatif untuk menjawab isu hukum yang dihadapi. Indonesia seharusnya melindungi merek terkenal meskipun belum terdaftar dalam daftar umum merek, seperti yang telah diatur dalam Perjanjian TRIPs dan Konvensi Paris. Perjanjian TRIPs dan Konvensi Paris harus dijadikan sebagai sumber hukum oleh Indonesia sebagai konsekuensi keikutsertaan dalam World Trade Organization (WTO) untuk memberikan perlindungan dan kepastian hukum bagi pemilik merek terkenal.
\end{abstract}

Kata kunci: Perlindungan Merek; Merek Terkenal; First to File.

\footnotetext{
${ }^{1}$ Merupakan artikel hasil penelitian mandiri yang dilakukan oleh penulis pada tahun 2019 .
} 


\section{A. Pendahuluan}

Negara Indonesia pada umumnya menganut sistem konstitutif, dimana merek baru mendapatkan perlindungan hukum setelah dilakukan pendaftaran (first to file). Namun penulis menilai sistem first to file belum memberikan jaminan kepastian hukum bagi pemegang merek terkenal yang sebenarnya. Seharusnya, dalam pendaftaran merek, merek yang mempunyai kesamaan pada pokoknya dan atau keseluruhannya dengan merek terkenal harus ditolak oleh Kantor Merek. Membangun sebuah merek hingga memiliki daya pembeda bukanlah sesuatu yang mudah, karena dibutuhkan upaya dalam bentuk kreativitas, waktu dan dana. Oleh karenanya, orang yang telah menginventasikan upaya untuk membangun merek perlu mendapatkan perlindungan (Wauran, 2017). Kaidah hukum dalam rangka perlindungan terhadap merek terkenal dalam aturan hukum internasional dapat ditemukan dalam Konvensi Paris (Paris Convention for the Protection of Industrial Property 1967) Pasal 6 bis ayat 91), serta Perjanjian TRIPs Pasal 16 ayat (2) dan (3) (Kurnia, 2011). Setiap negara anggota memiliki kewajiban internasional untuk memasukkan TRIPs ke dalam hukum nasional tentang hak kekayaan intelektual (Astarini, 2009) . Selain itu, kantor merek harus menerapkan asas kecermatan berkenaan dengan ketentuan tentang pemeriksaan terhadap merek yang hendak didaftarkan oleh Kantor Merek dan juga pertimbangan terhadap kepentingan pihak ketiga (antara lain bahwa pendaftaran merek tidak dapat diterima dan dapat ditolak jika memiliki persamaan pada pokoknya dengan pihak lain) (Kurnia, 2011).

Ketiadaan norma eksplisit pada konstitusi yang menjelaskan kedudukan hukum internasional dalam sistem hukum nasional tidak serta merta menghilangkan kemampuan suatu negara untuk memanfaatkan hukum internasional dalam ruang domestik (Melatyugra, 2015). Rezim hukum internasional tentang HKI tidak mungkin efektif tanpa ditransformasi ke dalam hukum nasional, begitupun sebaliknya rezim hukum nasional juga harus mengindahkan kaidah-kaidah dalam rezim hukum internasional tentang HKI dengan tujuan untuk keseragaman pengaturan tentang HKI (Kurnia, 2011). Kasus merek terkenal di antaranya kasus Merek Pierre Cardin melawan Alexander Satryo Wibowo dengan Putusan Nomor 557 K/Pdt.SusHKI/2015, dan kasus Merek Prada S.A melawan PT. Manggala Putra Perkasa dengan Nomor Putusan Nomor 449 K/Pdt.Sus-HKI/2014 yang mana Hakim memenangkan pemohon yang mendaftarkan merek terkenal di Indonesia dengan itikad tidak baik. Beberapa kasus tersebut menjelaskan bahwa perlindungan merek terkenal asing di Indonesia masih belum memberikan kepastian hukum bagi pemegang merek terkenal yang seharusnya. Dalam bukunya Titon menyebutkan belum diaturnya secara spesifik dalam peraturan perundang-undangan tentang merek terkenal tidak lantas membuat pengadilan berpangku tangan ketika pemilik merek terkenal dilanggar haknya meskipun merek tersebut belum didaftarkan di dalam yurisdiksi Indonesia oleh pihak yang tidak berhak, pemilik merek terkenal tersebut tetap mendapatkan perlindungan. Penggunaan merek yang memiliki persamaan pada keseluruhannya atau pada pokoknya dengan merek terkenal harus selalu dianggap menngandung unsur bad faith (Kurnia, 2011).

Negara Indonesia merupakan satu dari beberapa negara yang tergabung dalam WTO, sehingga perlindungan terhadap merek terkenal merupakan konsekuensi pengakuan Indonesia terhadap TRIPs (Agreement on Trade Related Aspects of Intellectual Property Rights) tidak dapat dipisahkan dari Pengakuan Indonesia terhadap Organisasi Perdagangan Dunia (World Trade Organization) (Maulana, 2000a). Selain diatur dalam Perjanjian TRIPs, merek terkenal juga diatur dalam Konvensi Paris. Konvensi Paris memberikan perlindungan untuk merek yang dikenal di suatu negara bahkan ketika merek tersebut tidak digunakan atau didaftarkan di negara 
tersebut jika pihak ketiga: 1) mendaftarkan atau menggunakan merek yang sama atau serupa; dan/atau 2) menggunakan merek yang sama atau serupa dengan cara yang merupakan persaingan tidak adil (Lackert \& Perry, 2008). TRIPs mensyaratkan terjadinya kebingungan (Wauran, 2017). Untuk menemukan terjadinya kebingungan, pengadilan memeriksa faktor-faktor seperti kesamaan merek, sifat barang, layanan atau bisnis (Chong, 2005). Perjanjian TRIPs pada hakikatnya merupakan jembatan atas gap yang selama ini ada menyangkut pengaturan tentang HKI di negara-negara karena memang pada hakikatnya bahwa HKI sebagai bagian dari Hukum Benda (Property Law) merupakan ranah atau domain hukum nasional sebagaimana hal itu mengikuti asas yang berlaku yaitu asas teritorial (Kurnia, 2011). Kepatuhan negara terhadap hukum Internasional mengantarkan negara ke tahap selanjutnya yakni bagaimana negara tersebut dapat menggunakan hukum internasional di wilayah nasional (Melatyugra, 2015).

Teori Internasionalisme menjadi solusi yang lebih memadai bagi negara seperti Indonesia yang memiliki keterbatasan dalam konstitusi untuk menggunakan hukum internasional secara proporsional (Melatyugra, 2015). Pengaturan mengenai merek terkenal dalam TRIPs dan Konvensi Paris melarang penggunaan merek yang mempunyai persamaan pada pokoknya dan/atau keseluruhannya dengan merek terkenal yang menimbulkan kebingungan di kalangan masyarakat. Perjanjian internasional dapat diartikan sebagai sumber hukum yang terpenting dalam dewasa ini (Sefriani, 2018). Dengan kata lain jika konstitusi sendiri mengakui hukum internasional sebagai sumber hukum, maka TRIPs sebagai salah satu perjanjian internasional pun harusnya dijadikan sebagai sumber hukum oleh negara anggota.

Penelitian mengenai merek terkenal juga pernah ditulis oleh Titon Slamet Kurnia dalam bukunya yang berjudul "Perlindungan Hukum Terhadap Merek Terkenal di Indonesia Pasca Perjanjian TRIPs". Penulis membahas mengenai pengaturan internasional tentang HKI dan perlindungan terhadap merek terkenal di Indonesia, dan kaidah-kaidah perlindungan hukum terhadap merek terkenal di Indonesia. Kemudian, Intan Purnamasari dalam skripsinya dengan judul "Perlindungan Hukum Terhadap Merek Terkenal di Indonesia". Penulis membahas mengenai ketentuan penghapusan merek yang tidak digunakan selama tiga tahun berturut-turut untuk merek terkenal. Catur Berkat Setiono dalam skripsinya dengan judul "Perlindungan Hukum Merek Terkenal untuk Beda Jenis Barang (Studi Kasus IKEA vs IKEMA)". Penulis membahas mengenai perlindungan merek terkenal yang didaftarkan dengan jenis barang yang berbeda. Serta, jurnal oleh Vania Isura Sitepu, dengan judul "Pelaksanaan Prinsip First to File dalam Penyelesaian Sengketa Merek Dagang Asing di Pengadilan (Studi Kasus tentang Gugatan Pencabutan Hak Merek "TOAST BOX" oleh BreadTalk Pte.Ltd No. 02/Merek/2011/PN.Niaga/Medan)". Penulis membahas mengenai perlindungan hukum terhadap merek dagang asing di Indonesia menurut Undang-Undang No. 15 tahun 2001 tentang Merek, dan pelaksanaan prinsip first to file dalam penyelesaian sengketa merek dagang asing dalam peradilan di Indonesia, dan penyelesaian sengketa merek dagang asing yang mempunyai persamaan pada pokoknya atau keseluruhannya dengan merek terdaftar di Indonesia.

Dalam penelitian ini penulis membahas mengenai merek terkenal asing tetap mendapatkan perlindungan meskipun belum terdaftar di daftar umum merek Indonesia. Perlindungan merek terkenal diatur dalam Perjanjian TRIPs sehingga walaupun Negara Indonesia menganut sistem prinsip first to file, di mana pendaftar pertama yang akan mendapatkan perlindungan, namun dengan mengacu pada TRIPs maka walaupun belum didaftarkan di Indonesia, kantor Pendaftaran Merek harus menolak merek yang mempunyai persamaan pada pokoknya dan/atau keseluruhannya dengan merek terkenal asing. Dalam penelitian ini terdapat 2 (dua) tujuan, di antaranya pertama untuk 
mengetahui perlindungan merek terkenal khususnya merek terkenal asing di Indonesia, kedua untuk mengetahui apakah merek terkenal asing yang tidak terdaftar di Indonesia tetap mendapatkan perlindungan.

\section{B. Metode Penelitian}

Metode dalam penelitian ini adalah penelitian hukum. Penelitian hukum adalah suatu proses untuk menemukan aturan hukum, prinsip-prinsip hukum, maupun doktrin-doktrin hukum guna menjawab isu hukum yang dihadapi. Penulis menggunakan pendekatan undang-undang. Pendekatan undang-undang dilakukan dengan menelaah semua undang-undang dan regulasi yang bersangkutpaut dengan isu hukum yang sedang ditangani. Selain menggunakan pendekatan undang-undang penulis juga menggunakan pendekatan kasus. Pendekatan kasus dilakukan dengan cara melakukan telaah terhadap kasus-kasus yang berkaitan dengan isu yang dihadapi yang telah menjadi putusan pengadilan yang telah mempunyai kekuatan hukum tetap. Selain pendekatan kasus penulis menggunakan pendekatan komparatif. Pendekatan komparatif dilakukan dengan membandingkan undang-undang suatu negara dengan undang-undang-undang satu negara atau lebih negara lain mengenai hal yang sama. Pendekatan yang terakhir yang digunakan penulis adalah pendekatan konseptual. Pendekatan konseptual dilakukan dengan mempelajari pandanganpandangan dan doktrin-doktrin di dalam ilmu hukum (Marzuki, 2010).

Pengumpulan data berupa bahan-bahan hukum. Di antaranya antara lain; bahan hukum primer, yaitu Undang-Undang No. 20 Tahun 2016 tentang Merek dan Indikasi Geografis, serta beberapa putusan mahkamah agung terkait merek, di antaranya Putusan No. 449 K/Pdt.SusHKI/2014, dan Putusan No. 557 K/Pdt.Sus$\mathrm{HKI} / 2015$. Di samping peraturan perundang-undangan dan putusan pengadilan sebagai bahan hukum primer digunakan bahan hukum sekunder, yaitu literatur buku dan internet yang berkaitan dengan hak merek serta penelitian yang berkaitan dengan hak merek. Seluruh data yang didapat dianalisis dengan metode normatif.

\section{Hasil dan Pembahasan}

\section{Merek Terkenal sebagai Bagian dari Hak Kekayaan Intelektual}

\section{a. Pengertian Merek Secara Umum}

Pengertian merek diatur dalam Pasal 1 ayat (1) Undang-Undang Merek, yaitu tanda yang dapat ditampilkan secara grafis berupa gambar, logo, nama, kata, huruf, angka susunan warna, dalam bentuk 2 (dua) dimensi dan/atau lebih unsur tersebut untuk membedakan barang dan/atau jasa yang diproduksi oleh orang atau badan hukum dalam kegiatan perdagangan barang dan/atau jasa. Secara lebih khusus, dunia industri dan perdagangan mengenal merek sebagai tanda visual yang berfungsi sebagai identitas, sebagai pengenal atau sebagai pembeda barang di pasar (Parinduri, 2013).

Berdasarkan pengertian yang telah dijelaskan di atas, terdapat beberapa unsur dalam merek, di antaranya: a) tanda; b) memiliki daya pembeda; dan c) digunakan dalam perdagangan barang dan jasa. Sebuah merek dapat disebut merek apabila memenuhi syarat mutlak berupa adanya daya pembeda yang cukup (capable of distinguishing), maksudnya yang dipakai tersebut memiliki kekuatan untuk membedakan barang atau jasa yang diproduksi suatu perusahaan dari perusahaan lainnya (Marwiyah, 2010).

\section{b. Jenis-Jenis Merek}

Dalam Undang-Undang Merek dikenal 2 (dua) kategori merek, yaitu Merek Dagang dan Merek Jasa. Merek dagang adalah merek yang digunakan pada barang yang diperdagangkan oleh seseorang atau beberapa orang secara bersama-sama atau badan hukum untuk 
membedakan dengan barang sejenis lainnya. Sedangkan Merek Jasa, adalah merek yang digunakan pada jasa yang diperdagangkan oleh seseorang atau badan hukum untuk membedakan dengan jasa sejenis lainnya. Merek berdasarkan kepemilikannya, Merek kolektif, yaitu merek yang digunakan pada barang dan/jasa dengan karakteristik yang sama mengenai sifat, ciri umum, dan mutu barang atau jasa serta pengawasannya yang akan diperdagangkan oleh beberapa orang atau badan hukum secara bersama-sama untuk membedakan dengan barang dan/atau jasa sejenis lainnya.

Berdasarkan keterkenalannya, umumnya para ahli membedakan tingkat kemashuran atau tingkat keterkenalan yang dimiliki berbagai merek antara lain: Merek biasa (normal mark) yang tidak memiliki reputasi tinggi, jangkauan pemasaran merek biasa terbatas dalam kawasan lokal dan belum mampu melintasi pasar nasional atau regional. Merek terkenal (wellknown mark) merek yang memiliki reputasi tinggi yang menimbulkan keakraban pada setiap lapisan konsumen. Merek termashur (famous mark) merek ini mempunyai derajat yang lebih tinggi dari merek biasa maupun merek terkenal (Gunawati, 2015). Yahya Harahap menjelaskan perbedaan merek terkenal dan merek termashyur. Merek terkenal mempunyai kekuatan pancaran yang memukau dan menarik, sehingga jenis barang yang berada di bawah merek itu langsung menimbulkan sentuhan keakraban (familiar) dan ikatan mitos (mythical context) kepada segala lapisan konsumen. Sedangkan merek termasyur adalah merek yang sedemikian rupa mashyurnya di seluruh dunia, sehingga mengakibatkan reputasinya digolongkan sebagai merek aristrokat dunia (Sari D, 2015). A Wellknown trademark is sometimes called a famous trademark. However, differences exist between the two notions, and it appears that the standard for archieving famous trademark status is higher than that required for well-known trademark status (World Intellectual Property Organization, 2010). (merek terkenal kadang disebut juga sebagai merek termashur, namun ada perbedaan antara kedua gagasan tersebut. Standar untuk mencapai status sebagai merek termashur lebih tinggi daripada yang dibutuhkan untuk mencapai status sebagai merek terkenal).

\section{c. Kriteria Merek Terkenal}

Yurisprudensi Mahkamah Agung R.I. Nomor 1486 K/Pst/1991 tertanggal 28 November 1995 dengan tegas memberikan kriteria hukum sebagai berikut: "Suatu merek termasuk dalam pengertian Well Known Mark pada prinsipnya diartikan bahwa merek tersebut telah beredar keluar dari batasbatas regional malahan sampai batasbatas transnasional, karenanya apabila terbukti suatu merek telah terdaftar di banyak negara di dunia, maka dikualifisir sebagai merek terkenal karena telah beredar sampai ke batasbatas di luar negara asalnya." Sementara itu Cina juga sebagai salah satu negara anggota WTO. mengeluarkan Ketentuan tentang Penentuan dan Perlindungan Merek terkenal, kemudian disebut Order No. 5 yang memberikan pengertian merek terkenal sebagai berikut; Article 2 of Order 5 provides that " a well known mark refers to a mark that is widely known to the relevant sectors of the public and enjoys a relatively high reputation in China" (Qinghu, 2005). (Merek terkenal, merupakan merek yang dikenal luas dalam sektor publik dan memiliki reputasi yang relatif tinggi di Cina).

WIPO juga memberikan kriteria merek terkenal dalam negara anggota, di antaranya sebagai berikut (World Intellectual Property Organization, 
1999) : 1) the degree of knowledge or recognition of the mark in the relevant sector of the public (Derajat pengetahuan atau pengenalan atas merek tersebut di kalangan masyarakat atau bidang usaha yang relevan); 2) the duration, extent and geographical area of any use of the mark (Lamanya, luasnya dan lingkup wilayah pemakaian merek yang bersangkutan); 3) the duration, extent and geographical area of any promotion of the mark, including advertising or publicity and the presentation, of fairs or exhibitions, of the goods an/or services to which the mark applies (Lamanya, luasnya dan lingkup wilayah promosi dan merek yang bersangkutan, termasuk pemasangan iklan atau publisitas dan presentasi dari barang-barang atau jasa yang menggunakan merek tersebut dalam pekan-pekan raya atau pameranpameran); 4) the duration and geographical area of any registration, and/or any applications for registration, of the mark, to the extent that they reflect use or recognition of the mark (Lamanya dan lingkup wilayah pendaftaran, dan/atau permintaan pendaftaran dari merek yang bersangkutan, yang menunjukkan pemakaian atau pengenalan akan merek tersebut); 5) the record of successful enforcement of rights in the mark, in particular, the extent to which the mark was recognized as well known by competent authorities (Catatan keberhasilan dari upaya penegakan hukum atas merek tersebut, khususnya yang berkaitan dengan pengenalan akan keterkenalan merek tersebut oleh pihak yang berwenang); 6) the value associated with the mark (Nilai (komersil) yang berkaitan dengan merek tersebut).

Well known atau famous mempunyai arti dikenal secara luas oleh banyak orang di suatu area tertentu. "Well-known", "famous" dan "popular" mempunyai arti yang sama. Merek terkenal digunakan secara populer oleh suatu komunitas, sehingga mudah dikenal dan diidentifikasi oleh konsumen (Tam, 2011). Pengadilan di Jerman menentukan kriteria merek itu famous apabila hasil survey menunjukan $\quad 80 \% \quad$ responden mengenalnya dan dianggap merek itu well-known apabila survey menunjukkan $40 \%$ responden cukup mengenalnya (Maulana, 2000b, p. 44) Selain diatur dalam WIPO, kriteria merek terkenal dapat dilihat dalam penjelasan pasal 21 huruf $b$ UndangUndang Merek, yaitu di antaranya: pertama, pengetahuan umum masyarakat mengenai merek tersebut; kedua, reputasi merek tersebut yang diperoleh dari promosi yang gencar dan besar-besaran; ketiga, investasi di beberapa negara di dunia disertai bukti pendaftaran merek yang dimaksud di beberapa negara; keempat survei yang dilakukan oleh lembaga yang bersifat mandiri untuk memperoleh kesimpulan mengenai terkenalnya merek tersebut atau tidak. Kriteria merek juga diatur dalam Pasal 18 Peraturan Menteri Hukum dan Hak Asasi Manusia Republik Indonesia No. 67 Tahun 2016 tentang Pendaftaran Merek.

Dilihat dari pengaturan merek terkenal di dalam Undang-Undang Merek, merek terkenal yang dimaksud yaitu mempunyai reputasi yang relatif tinggi yang diperoleh dari hasil promosi besar-besaran, selain memiliki reputasi yang tinggi kriteria berikutnya yaitu telah terdaftar di beberapa negara di luar batas regionalnya, serta dikenal dalam masyarakat luas karena reputasinya.

\section{d. Prinsip First to File}

Indonesia menganut sistem konstitutif di mana diberlakukan prinsip first to file, yang mana pengertian dari prinsip first to file adalah perlindungan yang diberikan kepada orang yang pertama kali mendaftarkan mereknya (Wauran, 2017) . Hak atas merek hanya 
diberikan kepada merek yang terdaftar, artinya untuk mendapatkan hak merek maka pemilik merek harus mendaftarkan mereknya ke Kantor Merek (Chuzaibi, 2011). Perlindungan hukum pada sistem konstitutif atau first to file didasarkan atas pendaftar pertama yang beritikad baik (Usman, 2003, p. 326). Pendaftaran merek memiliki tujuan tertentu di antaranya perlindungan pemilik merek, perlindungan konsumen, perlindungan masyarakat melalui pencegahan dan penanggulangan segala bentuk persaingan curang. Dalam hal pendaftaran merek tidak dapat diterima permohonan merek apabila dilatarbelakangi oleh itikad buruk (Sari, 2014). Namun, merek yang tidak terdaftar mendapat perlindungan sepanjang merek tersebut merupakan merek terkenal, dan apabila bukan merek terkenal maka komitmen perlindungannya diaktualisasikan dalam bentuk pemberian kesempatan untuk mengajukan pernyataan keberatan (Soelistyo, 2017).

\section{Perlindungan Merek Terkenal secara Preventif oleh Kantor Pendaftaran}

\section{a. Pendaftaran sebagai Mekanisme Preventif}

Dianutnya prinsip first to file di Indonesia menunjukkan pentingnya peran kantor pendaftaran merek dalam rangka memberikan kepastian dan perlindungan hukum kepada pemilik merek. Berdasarkan prinsip tersebut maka seseorang yang ingin memiliki hak atas merek harus melakukan pendaftaran atas merek yang bersangkutan (Sugiarti, 2016). Perlindungan merek secara preventif, yakni melakukan pencegahan terjadinya pelanggaran merek dagang melalui saran-saran kepada pemilik merek untuk mendaftarkan mereknya agar dapat dilindungi secara hukum (Taliwongso, 2014). Perlindungan preventif bertujuan untuk meminimalisasi peluang terjadinya pelanggaran merek dagang. Langkah ini difokuskan pada pengawasan pemakaian merek, perlindungan terhadap hak eksklusif pemegang hak atas merek dagang terkenal, serta anjuran-anjuran kepada pemilik merek untuk mendaftarkan mereknya agar haknya terlindungi. Pendaftaran menurut Undang-Undang Merek memberikan hak eksklusif kepada perusahaan pemilik merek guna mencegah pihak-pihak untuk memasarkan produk-produk yang identik atau mirip dengan merek yang dimiliki oleh perusahaan bersangkutan dengan menggunakan merek yang sama atau merek yang dapat membingungkan konsumen. Tanpa adanya pendaftaran merek perusahaan pesaing dapat memanfaatkan merek yang sama atau yang mirip untuk memasarkan produknya, sehingga dapat mengurangi keuntungan perusahaan, juga termasuk merusak reputasi perusahaan apabila kualitas produk pesaing lebih rendah, terutama apabila perusahaan tersebut memiliki merek terkenal (Nurhidayati, 2017).

Perlindungan hukum preventif diberikan dengan cara pendaftaran merek. Sebenarnya tidak ada kewajiban bagi seseorang untuk mendaftarkan merek yang dimiliki, namun jika ingin mendapat perlindungan hukum, maka merek yang bersangkutan harus terdaftar terlebih dahulu. Hak atas merek didasarkan atas pemakaian pertama dari merek tersebut, yang mendaftarkan mereknya dianggap oleh undang-undang sebagai pemakai pertama (Mamahit, 2013). Merek didaftarkan untuk mendapatkan landasan hak sekaligus perlindungan hukum melalui kewenangannya mencegah pihak lain menggunakan merek yang sama atau sama pada pokoknya (Soelistyo, 2017). Pendaftaran merek yang mempunyai persamaan pada pokoknya dan/atau 
keseluruhannya dengan merek terkenal yang menciptakan kebingungan di kalangan masyarakat harus ditolak oleh kantor merek, hal ini sesuai dengan Undang-Undang Merek, Pasal 16 TRIPs, Pasal 6 bis Konvensi Paris dan Yurisprudensi terkait dengan merek terkenal untuk mencegah terjadinya pelanggaran merek.

Terkait dengan ketentuan dari Protocol Madrid yang telah memudahkan bagi merek (termasuk merek terkenal) untuk didaftarkan di beberapa negara sekaligus tentu akan memudahkan merek dari negara lain baik yang terkenal maupun tidak terkenal untuk terdaftar di Indonesia. Namun demikian, tidak menutup kemungkinan ada merek terkenal yang tidak mendaftarkan diri di Indonesia. Pada praktiknya hal ini masih menimbulkan kebingungan mengenai bagaimana hukumnya terkait dengan merek terkenal yang tidak didaftarkan (lebih lanjut dibahas pada bagian selanjutnya). Namun demikian, Protocol Madrid merupakan terobosan yang sangat penting dalam menjadikan pendaftaran sebagai tindakan pencegahan terjadinya pelanggaran merek. Sehingga dapat dikatakan bahwa pendaftaran merupakan bentuk perlindungan merek secara preventif.

\section{b. Asas Kecermatan oleh Kantor Pendaftaran Merek}

Sistem konstitutif yang dianut oleh hukum merek Indonesia menunjukkan betapa pentingnya makna lembaga pendaftaran merek dalam rangka memberikan perlindungan hukum kepada pemegang/pemilik merek. Dalam pemeriksaan permohonan pendaftaran merek diberlakukan beberapa asas pemerintahan yang baik. Oleh karena pemeriksaan permohonan pendaftaran merek yang diakhiri dengan dikeluarkannya sertifikat bukti pendaftaran merek merupakan salah satu tindakan dalam penyelenggaran pemerintah. Pasal 1 angka 17 UndangUndang No. 30 Tahun 2014 tentang Administrasi Pemerintah menyebutkan Asas Umum Pemerintahan yang Baik yang selanjutnya disingkat AUPB adalah prinsip yang digunakan sebagai acuan penggunaan wewenang bagi Pejabat Pemerintahan dalam mengeluarkan Keputusan dan/atau Tindakan dalam penyelenggaraan pemerintah. AUPB berfungsi untuk memberikan perlindungan hukum kepada pemilik merek terkenal dengan jalan mencegah supaya tidak terjadi pendaftaran merek dengan itikad tidak baik atau pendaftaran merek oleh pihak yang tidak berhak yang memiliki persamaan pada pokoknya dan atau keseluruhannya dengan merek terkenal (Kurnia, 2011).

Dalam pendaftaran merek, Asas umum pemerintahan yang baik sangat penting untuk mencegah supaya tidak terjadi persamaan pada pokoknya atau pada keseluruhannya dengan merek pihak lain. Asas penting yang perlu diterapkan dalam Kantor merek dalam pemeriksaan substantif adalah asas kecermatan. Penjelasan asas kecermatan menurut UU AP 2014 adalah asas yang mengandung arti bahwa suatu Keputusan dan/atau Tindakan harus didasarkan pada informasi dan dokumen yang lengkap untuk mendukung legalitas penetapan dan/atau pelaksanaan Keputusan dan/atau Tindakan, sehingga Keputusan dan/atau Tindakan yang bersangkutan dipersiapkan dengan cermat, sebelum Keputusan dan/atau Tindakan tersebut ditetapkan dan/atau dilakukan. Asas kecermatan berkenaan dengan ketentuan tentang pemeriksaan terhadap merek yang hendak didaftarkan oleh Kantor Merek dan juga pertimbangan terhadap kepentingan pihak ketiga (antara lain bahwa pendaftaran merek tidak dapat diterima dan dapat ditolak jika memiliki persamaan pada pokoknya dengan pihak lain; hak pihak ketiga 
untuk mengajukan banding). Merek yang akan didaftarkan harus memiliki daya pembeda dari merek-merek lainnya yang diharapkan dapat menjadi keunikan yang mencerminkan orisinalitas produk tersebut (Perdana, 2017).

Kegiatan pendaftaran merek merupakan bentuk tindak pemerintahan yang dalam hukum administrasi diklasifikasikan sebagai beschikking. Kegiatan pendaftaran merupakan salah satu bentuk tindak pemerintahan. Dikabulkannya permohonan pendaftaran merek (dengan Kantor Merek menerbitkan Sertifikat Merek) pada hakikatnya dapat dikonstruksikan sebagai bentuk izin yang diberikan negara kepada pemilik merek (pihak yang mendaftarkan mereknya) untuk menggunakan sendiri merek tersebut atau untuk memberikan izin menggunakan merek tersebut kepada pihak ketiga. Melalui mekanisme pendaftaran merek yang didasari pada kecermatan pihak Kantor Merek, kerugian di pihak pemilik merek dapat dicegah. Dalam kaitannya dengan itu muncul tuntutan kepada Kantor Merek supaya berlaku cermat dan hati-hati dalam melakukan kegiatan pendaftaran merek. Jika kemudian bahwa ternyata merek yang didaftar memiliki persamaan pada pokoknya atau pada keseluruhannya dengan merek, hal itu disebabkan oleh pelaksanaan fungsi dan kewenangan pada Kantor Merek yang kurang memperhatikan asas rechmatigheid van bestuur (Kurnia, 2011).

Dalam kurun waktu 5 (lima) tahun, Kantor pendaftaran merek telah diperintahkan oleh Mahkamah Agung untuk menghapus sejumlah pendaftaran merek dengan alasan mempunyai kesamaan pada pokoknya, dan/atau keseluruhannya dengan merek terkenal dan didaftarkan atas itikad tidak baik, yang seharusnya pendaftarannya sudah dapat diantisipasi. Merek-merek yang diperintahkan untuk dihapus di antaranya adalah Perkara merek Merek Bodycology vs. Bodycology (Putusan Mahkamah Agung No. 364 K/Pdt.SusHKI/2014), Merek GS vs. GS Garuda Sakti (Putusan Mahkamah Agung No. 55 K/Pdt,Sus-HKI/2015), Merek ST. REGIS vs. REGIS@The Peak at Sudirman (Putusan Mahkamah Agung No. 7 K/Pdt.Sus-HKI/2016), Merek J. CASANOVA vs. CASANOVA (Putusan Mahkamah Agung No. 968 K/Pdt.Sus-HKI/2016), Merek ZORRIK vs. Zorrik (Putusan Mahkamah Agung No. 58 K/Pdt.Sus-HKI/2017), Merek HUGO BOSS vs. HUGO (Putusan Mahkamah Agung No.92 K/Pdt.SusHKI/2017), Merek Gudang Garam vs. Gudang Baru (Putusan Mahkamah Agung No. 119 PK/Pdt.Sus-HKI/2017), Merek HUGO BOSS vs. ZEGOBOSS (Putusan Mahkamah Agung No. 938 K/Pdt.Sus-HKI/2017), Merek EIK vs. EIKA (Putusan Mahkamah Agung No. 1300 K/Pdt.Sus-HKI/2017), dan Merek BOSSINI dan Logo vs. BOSSINI (Putusan Mahkamah Agung No. 111 PK/Pdt.Sus-HKI/2018).

Putusan di atas merupakan contoh kasus di mana kurangnya kecermatan Kantor Merek dalam menerima pendaftaran merek yang mempunyai persamaan pada pokoknya dan/atau keseluruhannya dengan merek terkenal, sehingga mengakibatkan kerugian bagi pemilik merek. Sehingga kecermatan oleh Kantor Merek sangat diperlukan untuk mencegah terjadinya pendaftaran merek oleh pemohon yang beritikad tidak baik (Kurnia, 2011).

\section{c. Penolakan Permohonan Pendaftaran Merek yang Mempunyai Kesamaan Pada Pokoknya dan/atau Keseluruhannya dengan Merek Terkenal}

Prinsip perlindungan merek di Indonesia adalah memberikan perlindungan atas merek terdaftar 
dengan good faith (itikad baik). Jika mengandung kemiripan, maka pemohon pendaftaran itu dianggap beritikad tidak baik. Jadi ukurannya dikuantifikasikan ke dalam fakta hukum mengenai ada tidaknya persamaan pada pokoknya antara merek yang akan didaftarkan tersebut dengan merek yang telah terdaftar terlebih dahulu merek orang lain. Sementara itu, apabila menyangkut kemiripan dengan merek terkenal, maka tidak dipersyaratkan merek pembanding itu telah terdaftar di Indonesia. Pendeknya meski merek terkenal tidak terdaftar di Kantor Merek Indonesia, merek serupa itu tetap digunakan sebagai pembanding. Bila sama atau secara pokok serupa, maka pendaftaran akan ditolak.

Jika merek asing sudah dikenal tapi tidak digunakan dalam kegiatan perdagangan di Indonesia, maka pendaftaran merek serupa itu yang diajukan oleh bukan pemilik yang sesungguhnya, dapat dikategorikan sebagai tindakan penyalahgunaan merek. Apalagi bila merek itu telah memiliki reputasi di luar negeri. Ketentuan dalam Article 6 bis Konvensi Paris memberikan perlakuan melebihi aturan standar, yaitu memberi kewenangan pada Kantor Merek untuk menolak atau membatalkan pendaftaran merek yang telah terlanjur diberikan, serta melarang penggunaan merek atau menyerupai merek terkenal (Soelistyo, 2017).

Permohonan merek harus ditolak apabila diajukan oleh pihak yang beritikad tidak baik (Pasal 21 ayat (3)). Penjelasan Pasal 21 ayat (3) memberikan penjelasan mengenai pemohon yang beritikad tidak baik, yaitu pemohon yang patut diduga dalam mendaftarkan mereknya memiliki niat untuk meniru, menjiplak, atau mengikuti merek pihak lain demi kepentingan usahanya menimbulkan kondisi persaingan usaha tidak sehat, mengecoh, atau menyesatkan konsumen. Penolakan pendaftaran merek jika memiliki persamaan pada pokoknya dan atau keseluruhannya dengan merek terkenal oleh Kantor Merek mengandung asas bahwa seseorang tidak boleh memperoleh keuntungan dari hasil jerih payah orang lain secara tanpa hak, yang mana memetik keuntungan dari hasil jerih payah orang lain secara tanpa hak sama halnya dengan bertindak merugikan orang tersebut (Kurnia, 2011). Oleh karena itu pendaftaran merek melarang adanya persamaan pada pokoknya atau persamaan pada keseluruhannya.

Perlindungan represif diberikan dengan pembatalan pendaftaran merek oleh pengadilan. Yurisprudensi yang ada tentang merek terkenal berhasil diidentifikasi beberapa upaya pengadilan mengatasi kekosongan pengaturan hukum, antara lain, yaitu merek memiliki persamaan pada pokoknya dengan merek milik orang lain, itikad baik dalam pendaftaran merek, melindungi kepentingan masyarakat luas, menegakkan ketentuan tentang persaingan usaha yang sehat dengan mencegah praktik persaingan curang, dan kepentingan negara lain dalam kaitannya dengan perdagangan internasional (Kurnia, 2011). Mahkamah Agung memiliki perangkat kebijakan dalam memeriksa perkara merek untuk dijadikan pedoman oleh semua pengadilan di Indonesia. Oleh karena itu, Mahkamah Agung perlu mendapatkan apresiasi dalam konteks perlindungan merek terkenal asing.

Setidaknya undang-undang memerintahkan kepada pejabat pendaftar untuk menolak pendaftaran Merek apabila sama atau menyerupai Merek yang sudah terkenal yang sudah dimiliki oleh pihak lain, yang tentunya maksudnya tidak terdaftar (Murjiyanto, 2017). Asas dasar dalam hukum memberi pedoman berperilaku kepada setiap subjek hukum supaya tidak 
merugikan orang lain (alterum non laedere). Asas good faith sebagai bagian dari kewajiban pihak pendaftar merek untuk berbuat jujur ketika mengajukan pendaftaran, yaitu dengan tidak membonceng ketenaran merek pihak lain yang terkenal (Kurnia, 2011).

\section{Merek Terkenal yang Tidak Terdaftar Tetap Mendapatkan Perlindungan}

Dalam dunia perdagangan tercatat banyak merek-merek asing yang belum terdaftar di Indonesia, banyak pengusaha nakal yang membawa pulang merek asing untuk didaftar dan digunakan di Indonesia sehingga ketika pemilik merek aslinya datang untuk mendaftar, mereka terpaksa kecewa karena mereknya telah dikuasai orang lain di Indonesia secara tanpa ijin. Anotasi yang dibuat oleh Prof. Asikin Kusumah Atmadja dalam kasus Woodstock \& Snoopy (Putusan MARI No. 1272K/PDT/1984), menyatakan bahwa "Secara hukum sesuai dengan moral perdagangan yang baik para pedagang wajib menjauhkan diri dari segala usaha untuk membonceng pada ketenaran merek dagang milik orang lain (nasional/asing), Meskipun merek dagang tersebut belum terdaftar di Indonesia malah meskipun merek dagang tersebut (asing) belum masuk dalam wilayah Republik Indonesia" (Soelistyo, 2017).

Undang-Undang No. 20 Tahun 2016 telah mengatur mengenai perlindungan hukum bagi pemegang hak merek, namun penulis menilai masih kurang melindungi pemegang merek terkenal asing dari pelanggaran merek yang dilakukan oleh pihak yang beritikad tidak baik. Hal ini dapat dilihat dari prinsip pendaftaran dalam UU Merek yaitu prinsip first to file, di mana merek dilindungi jika telah terdaftar dalam daftar umum merek. Prinsip ini kemudian diikuti begitu saja oleh hakim dalam membuat putusannya sehingga merek terkenal asing yang belum terdaftar tidak dilindungi di Indonesia. Pengaturan yang lebih detail mengenai perlakuan yang seharusnya terhadap merek terkenal asing tidak dijumpai. Namun demikian, Indonesia sebagai salah satu negara anggota yang ikut serta dalam WTO melindungi merek terkenal sebagai konsekuensi pengakuan TRIPs.

Pasal 3 ayat (1) TRIPs mewajibkan setiap negara anggota untuk memberikan perlindungan tanpa membedakan di bidang HKI tanpa membedakan kepada sesama negara anggota. Berdasarkan prinsip National Treatment, maka warga negara dari negara lain sesama negara anggota harus diakui sebagai subjek hukum yang memenuhi kriteria perolehan hak sebagaimana ditentukan Paris Convention (Jened, 2015). Selain TRIPs, merek terkenal juga diatur dalam Konvensi Paris. Pasal 6 bis Konvensi Paris memberikan perlindungan kepada pemilik merek terkenal untuk menolak atau membatalkan pendaftaran dan melarang penggunaan dari merek dagang yang merupakan reproduksi, imitasi, atau terjemahan yang dapat menimbulkan kebingungan. Sementara itu, Pasal 16 ayat (1) TRIPs mensyaratkan terjadinya kebingungan (likehood of confusion) yang sejatinya merupakan syarat terjadinya pelanggaran merek.

Yurisprudensi Mahkamah Agung R.I. Nomor $3485 \mathrm{~K} / \mathrm{pdt} / 1992$ tertanggal 20 September 1995, memberikan kriteria "Bahwa dalam Konvensi Paris juga telah diisyaratkan kepada seluruh peserta memberikan perlakuan yang sama dalam rangka melindungi merek terkenal dari manapun asalnya, karena Indonesia sendiri sebagai peserta dan ikut meratifisir hasil Konvensi Paris bahkan tanpa reserve dan oleh karena itu hasil Konvensi Paris itu harus ditaati". Perlindungan hukum terhadap merek terkenal merupakan isu yang bersifat lintas batas negara karena tidak lagi menyangkut kepentingan satu negara di dalam yurisdiksinya.

Perlindungan merek yang tidak terdaftar dapat ditemukan dalam Pasal 76 ayat (2) Undang-Undang Merek. Pasal 76 ayat (2) memberikan perlindungan terhadap pemilik merek tidak terdaftar untuk mengajukan gugatan pembatalan setelah mengajukan 
permohonan kepada menteri sebagaimana alasan yang dimaksud dalam Pasal 20 dan/atau 21 Undang-Undang Merek. Selain perlindungan hukum yang diberikan kepada pemilik merek tidak terdaftar untuk mengajukan gugatan pembatalan yang diatur dalam Pasal 76 ayat (2), perlindungan merek dalam bentuk gugatan atas pelanggaran merek juga diatur dalam Pasal 83 ayat (2) Undang-Undang Merek. Pasal 83 ayat (2) memberikan kesempatan kepada pemilik merek terdaftar dan pemilik merek terkenal untuk untuk mengajukan gugatan ganti rugi dan/atau penghentian penggunaan merek terhadap pihak lain yang secara tanpa hak menggunakan merek yang mempunyai persamaan pada pokoknya dan atau keseluruhannya dengan merek terkenal.

Pada hakikatnya, merek terkenal membawa dimensi perlindungan hukum yang bersifat lintas batas negara memang merupakan kenyataan yang tidak terelakkan (Kurnia, 2011). Seseorang yang melakukan pendaftaran suatu merek yang memiliki persamaan dengan merek terkenal tiada lain telah memiliki itikad buruk untuk membonceng (passing off) ketenaran merek terkenal tersebut. Membonceng ketenaran merek orang lain, terutama merek terkenal, merupakan tindakan yang beritikad buruk dan melawan hukum sehingga pengadilan dapat membatalkan pendaftarannya. Dalam kaitan ini, pendaftaran merek dengan itikad buruk merupakan salah satu kendala terbesar bagi merek dan para pemilik merek terkenal. Konvensi Paris mewajibkan negara anggota untuk menolak atau membatalkan pendaftaran dan melarang penggunaan merek yang merupakan hasil peniruan merek terkenal (Soelistyo, 2017).

\section{Simpulan dan Saran}

Berdasarkan hasil penelitian dan pembahasan ditarik kesimpulan Indonesia sebagai salah satu negara pihak dalam WTO juga turut meratifikasi TRIPs dan Konvensi Paris. Kurangnya pengaturan dalam Undang-Undang Merek mengenai Merek Terkenal, tidak mengakibatkan merek terkenal tidak mendapatkan perlindungan.
Meskipun Indonesia menganut prinsip first to file, di mana merek dilindungi jika telah terdaftar dalam daftar umum merek, namun untuk merek terkenal, meskipun belum terdaftar dalam daftar umum merek, harus tetap dilindungi. TRIPs dan Konvensi Paris memberikan perlindungan mengenai merek terkenal baik untuk merek terkenal terdaftar maupun merek terkenal yang tidak terdaftar. Merek terkenal baik terdaftar maupun tidak terdaftar dapat mengajukan gugatan atas pelanggaran merek. meskipun Indonesia menganut prinsip first to file, di mana merek dilindungi jika telah terdaftar dalam daftar umum merek, namun untuk merek terkenal meskipun belum terdaftar dalam daftar umum merek harus tetap dilindungi, hal ini sesuai dengan Pasal 16 TRIPs dan Pasal 6 bis Konvensi Paris. Sehingga merek yang didaftarkan dengan itikad tidak baik, yang mana mempunyai kesamaan pada pokoknya dan/atau keseluruhannya dengan merek terkenal harus ditolak oleh Kantor Merek, untuk mencegah terjadinya pelanggaran merek dan memberikan kepastian hukum bagi pemilik merek terkenal.

\section{DAFTAR PUSTAKA}

Astarini, D. R. (2009). Penghapusan Merek Terdaftar. Bandung: Alumni.

Chong, S. (2005). Protection of Famous Trademarks Against Use for Unrelated Goods and Service: A Comparative Analysis of the Law in the United States. the United Kingdom and Canada Recomendations for Canadian Law Reform.

Chuzaibi, A. F. (2011). Sistem Konstitutif Dalam UU No. 15 Tahun 2001 Tentang Merek Bagi UMKM. Jurnal Syiar Hukum, 13(2), 152-167.

Gunawati, A. (2015). Perlindungan Merek Terkenal Barang dan Jasa Tidak Sejenis Terhadap Persaingan Usaha Tidak Sehat. Bandung: Alumni.

Jened, R. (2015). Hukum Merek: Trademark Law Dalam Era Global dan Integrasi 
Ekonomi. Jakarta: Kencana.

Kurnia, T. S. (2011). Perlindungan Hukum Terhadap Merek Terkenal di Indonesia Pasca Perjanjian TRIP's. Bandung: Alumni.

Lackert, C. W., \& Perry, M. C. (2008). Global Protecting well-known and famous marks: a global perspective. King \& Spalding LLP.

Mamahit, J. (2013). PERLINDUNGAN HUKUM ATAS MEREK DALAM PERDAGANGAN BARANG DAN JASA1. Lex Privatum, 1(3), 90-100.

Marwiyah, S. (2010). Perlindungan Hukum Atas Merek Terkenal. De Jure Jurnal Syariah Dan Hukum, 2(1), 35-50.

Marzuki, P. M. (2010). Penelitian Hukum. Jakarta: Kencana.

Maulana, I. B. (2000a). Merek Terkenal Menurut TRIPs Agreement dan Penerapan dalam Sistem Merek Indonesia. Jurnal Hukum Ius Quia Iustum, 7(13), 119-129.

Maulana, I. B. (2000b). Pelangi HAKI dan Anti Monopoli. Jakarta: Yayasan Klinik HAKI.

Melatyugra, N. (2015). Teori Internasionalisme dalam Sistem Hukum Nasional. Refleksi Hukum, 9(2), 199208.

Murjiyanto, R. (2017). Konsep Kepemilikan Hak Atas Merek di Indonesia (Studi Pergeseran Sistem "Deklaratif'ke dalam Sistem "Konstitutif." Jurnal Hukum Ius Quia Iustum, 24(1), 52-72.

Nurhidayati, N. (2017). Perlindungan Merek Terkenal Menurut UU No. 15 Tahun 2001(Kasus Pierre Cardin Melawan Alexander Satriyo Wibowo). Jurnal Administrasi Kantor, 5(1), 9-26.

Parinduri, R. J. (2013). Interface Hukum Kekayaan Intelektual dan Hukum Persaingan (Penyalahgunaan HKI). Jakarta: Raja Grafindo Persada.
Perdana, K. ; P. (2017). Kelemahan Undangundang Merek dalam hal Pendaftaran Merek (Studi Atas Putusan Sengketa Merek Pierre Cardn). Jurnal Privat Law, 5(2), 84-92.

Qinghu, A. (2005). Well-Known Marks and China's System of Well-Known Mark Protection. Journal of the International Trademark Association, 718.

Sari D, S. N. I. (2015). Perlindungan Hukum Terhadap Merek Terkenal Berdasarkan Konvensi Paris Dan Perjanjian Trips Serta Penerapannya Berdasarkan Undang-Undang Nomor 15 Tahun 2001 Tentang Merek. Jurnal Yuridis, 2(2), 164-177.

Sari, M. Y. A. R. (2014). Passing off Dalam Pendaftaran Merek. Jurnal Yudisial, 7(3), 255-272.

Sefriani. (2018). Hukum Internasional Suatu Pengantar. Jakarta: Rajawali Press.

Soelistyo, H. (2017). Badfaith Dalam Hukum Merek. Jakarta: Maharsa Artha Mulia.

Sugiarti, Y. (2016). Perlindungan Merek Bagi Pemegang Hak Merek Ditinjau Dari Undang-Undang Nomor 15 Tahun 2001 Tentang Merek. Jurnal Jendela Hukum, 2(1), 32-41.

Taliwongso, R. N. Y. (2014). Perlindungan Hukum Atas Hak Kekayaan Intelektual Khususnya Merek di Indonesia. Jurnal Lex et Societatis, 2(8), 147.

Tam, P. N. (2011). Well-known Trademark Protection (A Comparative Study between The Laws of The European Union and Vietnam). Skandinavia: Faculty of Law Lund University.

Usman, R. (2003). Hukum Hak atas Kekayaan Intelektual, Perlindungan dan Dimensi Hukumnya di Indonesia. Bandung: Alumni.

Wauran, I. (2017). Pengantar Hukum Kekayaan Intelektual. Salatiga: Tisara 
Grafika.

World Intellectual Property Organization. (1999). Joint Recommendation Concerning Provisions of the Protection of Well-Known Marks adopted by the Assembly of the Paris Union for the Protection of Industrial Property and the General Assembly of the World Intellectual Property Organization.
Washington DC.

World Intellectual Property Organization. (2010). Well-Known Tradmark Protection Reference to the Japanese experiene sponsored by World Intelectual Property Organization (WIPO) in Collaboration with the Japan Patent Office. 8. 